https://doi.org/10.30910/turkjans.725809

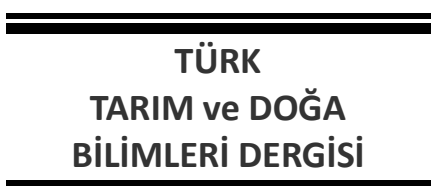

\section{(1)}
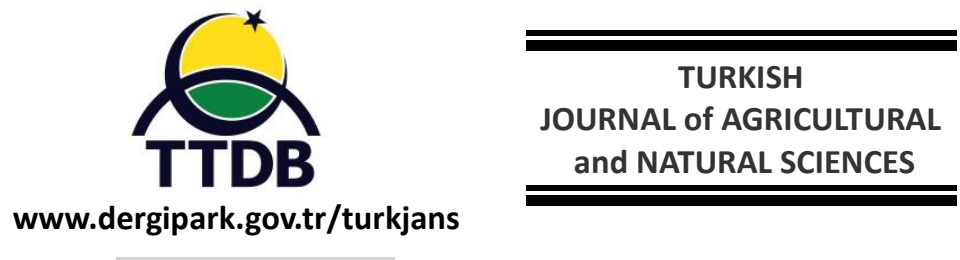

Araştırma Makalesi

\title{
Manisa İ Merkezinde Tüketicilerin Sofralık Zeytin Tüketim Alışkanlıklarının Belirlenmesi
}

\author{
Pelin GÜNÇ ERGÖNÜL* Deniz DINÇER \\ Manisa Celal Bayar Üniversitesi, Mühendislik Fakültesi, Gıda Mühendisliği Bölümü, Şehit Prof. Dr. İlhan \\ Varank Kampüsü, Yunusemre, Manisa \\ *Sorumlu yazar: pelingunc81@hotmail.com
}

Geliş Tarihi: 09.04.2019 Düzeltme Geliş Tarihi: 26.02.2020 Kabul Tarihi: 03.03.2020

\begin{abstract}
Özet
Bu çalışmada Manisa il merkezinde yaşayan farklı demografik özelliklere sahip, rastgele seçilmiş 400 bireye sofralık zeytin tüketimi, satın alma tercihleri ve sofralık zeytinin insan sağlığı üzerindeki etkilerinin ne derece bilindiğine yönelik 26 sorudan oluşan anket uygulanmıştır. Bu sayede tüketicilerin sofralık zeytin hakkındaki bilgi düzeyleri ve zeytin tüketim alışkanlıkları tespit edilip, üreticiye kaynak oluşturulması ve böylece sofralık zeytin tüketiminin arttırılması hedeflenmiştir. Cinsiyet, yaş ve gelir düzeyinin günlük zeytin tüketim miktarı üzerine etkisi önemsiz iken $(P>0,05)$, aylık zeytin tüketimi ile anlamlı bir ilişki tespit edilmiştir $(P<0.05)$. Ankete katılan bireylerin eğitim seviyelerinin artmasıyla zeytin hakkındaki bilgilerinin de arttığı saptanmıştır $(P<0.05)$. Sonuçlara göre tüketicilerin her biri her gün farklı miktarlarda zeytin tüketmekle birlikte, büyük bir kısmının zeytinin sağlığa yararı hakkındaki bilgisi orta ve düşük seviyelerde tespit edilmiştir. Bireylerin \%68.50'si zeytin tüketimi ile katarakt riskinden korunabileceğini, $\% 58.75^{\prime} i$ ise zeytinin yüksek E vitamini içeriğine bağlı olarak yaşlanmayı geciktirici etkisinin olduğunu bilmemektedir. Bu sebeplerle zeytinin alışılagelmiş tüketiminden ziyade sağlık açısından yararlarının tüketicilere bilimsel çalışmalarla ve/veya iletişim araçları ile ulaştırılarak bilgilendirmenin gerekli olduğu görülmüştür.
\end{abstract}

Anahtar Kelimeler: Zeytin tüketimi, zeytin tercihi, sofralık zeytin, tüketici tutumu

\section{Determination of Table Olive Consumption Habits of Consumers in Manisa City Center of Turkey}

\begin{abstract}
In this study, a questionnaire consisting of 26 questions about the consumption of table olives, purchasing preferences and the effects of table olives on human health was applied to 400 randomly selected individuals living in Manisa city center with different demographic characteristics. In this way, consumers' knowledge about table olives and olive consumption habits were determined and it was aimed to create resources for the producer and thus increase the consumption of table olives. While the effect of gender, age and income level on daily olive consumption was insignificant $(P>0.05), a$ significant correlation was found with monthly olive consumption $(P<0.05)$. It was also determined that the knowledge of the olives increased with the increase in the educational level of the individuals ( $P$ $<0.05$ ). According to the results, while each of the consumers consumed different amounts of olives every day, the majority of the knowledge about the health benefit of olives was determined at medium and low levels. $68.50 \%$ of the individuals can be protected from cataract risk by consumption of olives, $58.75 \%$ of olives due to high vitamin $\mathrm{E}$ content does not know that anti-aging effect. For these reasons, it is seen that the health benefits rather than the usual consumption of olives should be communicated to consumers through scientific studies and / or communication tools.
\end{abstract}

Key words: Olive consumption, olive preference, table olives, consumer behavior 


\section{Giriş}

Türk Gıda Kodeksi Sofralık Zeytin Tebliğine (No: 2014/33) göre sofralık zeytin, zeytin ağacı (Olea europaea L.) meyvelerinin tekniğine uygun olarak acılığının giderilip, fermantasyona bırakılıp ya da bırakılmadan gerekli olduğunda laktik asit ve/veya diğer katkı maddeleri ilave edilen, pastörizasyon veya sterilizasyon işlemi uygulanarak ya da uygulanmadan elde edilen ürün olarak tanımlanmaktadır (Savran ve Demirbaş, 2011).

Zeytin meyvesi çeşitli aşamalardan geçirilerek sofralık zeytin olarak tüketildiği gibi büyük bir kısmı ise içerdiği yağ oranının yüksek ve besleyici olması nedeniyle yemeklik yağ olarak tüketilmektedir (Özinanç, 2018). Her çeşit zeytin sofralık olarak işlenebilmektedir. Ancak kalitesinde farklılık olan, siyah-yeşil ve rengi dönük sofralık zeytinler farklı işleme teknikleri kullanılarak hazırlanmaktadırlar. Genellikle et oranı yüksek, çekirdeği küçük, etinden kolay ayrılabilir, ince ve esnek kabuklu, şeker oranı yüksek ve yağ oranı düşük çeşitler sofralık olarak tercih edilmektedir (Tiryakioğlu, 2011). Sofralık zeytin üretimi sağlıklı beslenme başta olmak üzere öz kaynakların değerlendirilmesi, istihdam yaratılması ve diğer sektörlere hammadde temini sebebiyle Türkiye tarım ekonomisinde önemli bir yere sahiptir (Çetin ve Tipi, 2000).

Türkiye'deki 88 zeytin çeşidinin \%74'ünü yağlık çeşit olan Memecik, ikinci önemli yağlık zeytin çeşidini ise Ayvalık Yağlık (Edremit) çeşidi oluşturmaktadır. Diğer önemli zeytin çeşitleri ise Gemlik, Domat, Uslu, Memeli, İzmir Sofralık, Yamalak, Edincik Su, Çelebi, Halhalı, Karamürsel Su, Çilli, Kaba, Erkence, Trilye olarak sıralanmaktadır (Sakar ve Ünver, 2011). Dünya sofralık zeytin üretimi ise son beş sezonda ortalama 2.74 milyon ton seviyesinde olup en önemli üretici ülkeler $A B$, Türkiye, Mısır, Cezayir, Fas ve Suriye olarak sıralanabilir. $A B$ ülkeleri içerisinde ilk sırayı İspanya alırken, onu Yunanistan ve italya takip etmektedir. Türkiye, Dünya sofralık zeytin üretiminde siyah sofralık zeytin üretimi ile ilk sırada yer alırken, yeşil sofralık zeytin üretiminde İspanya ilk sırada yer almaktadır (Anonim, 2018).

T.C. Ticaret Bakanlığı Kooperatifçilik Genel Müdürlüğü tarafından yayınlanan 2017 yılı Zeytin ve Zeytinyağı Raporu'nda; Türkiye'de 2000'li yılların başında 100 milyon adet olan zeytin ağacı sayısının 2016/17 sezonunda yaklaşık 174 milyon adede yükseldiği, son 5 yılın zeytinyağı üretim ortalamasının yaklaşık 159 bin ton, sofralık zeytin üretim ortalamasının 420 bin ton, yağlık zeytin üretiminin ise 1 milyon 300 bin ton olmak üzere 2016/17 yılında toplam zeytin üretiminin 1 milyon 730 bin ton olarak gerçekleştiği, Türkiye' de yaklaşık 320 bin aile işletmesi olduğu bildirilmiştir (Anonim, 2018). Türkiye'de zeytin üretimi yıllar itibariyle artış göstermiştir. Bunun en önemli nedenlerinden biri zeytin üretim alanlarının giderek artmasıdır. Tarım ve Orman Bakanlığı verilerine göre 2017 yılında Türkiye'de 2.1 milyon ton zeytin üretilmiştir (Çam, 2018). Toplam zeytin üretiminin yaklaşık olarak \%75'ini yağlık zeytin oluşturmaktadır. Yağlık zeytin üretiminde ise en önemli iller Aydın, İzmir, Muğla, Balıkesir ve Hatay'dır (Anonim, 2019). Çizelge 1'de Türkiye İstatistik Kurumu (TÜIK) ve Uluslararası Zeytin ve Zeytinyağı Konseyi (UZZK) 2018 verilerine göre Türkiye'de yıllara göre zeytin ve zeytinyağındaki değişim oranları verilmiştir (Anonim, 2019). Zeytin üretim alanları Ege ve Akdeniz bölgelerinde yoğunlaşmış ve yıllara göre artış göstermiştir. Bu kapsamda en önemli iller Aydın, Muğla ve İzmir'dir. Zeytin üretimi 2018 yılı 1 milyon 500 ton olarak belirlenmiştir (Anonim, 2019). Türkiye'de yıllara göre zeytin ağacı sayısı ve üretimin artış göstermesine rağmen sofralık zeytin ve zeytinyağı sektöründe İspanya, İtalya, Yunanistan ile rekabet edilememekte ve ihracatta istenilen hedeflere ulaşılamamaktadır. Bu nedenle birçok sektör raporu, fizibilite çalışmaları sonuçlarına göre Türkiye sofralık zeytin ve zeytinyağı ihracatı, yıldan yıla değişen zeytin üretim oranları ve buna bağlı olarak zeytinyağı üretiminde meydana gelen dalgalanmalar nedeniyle keskin artış ve azalışlar gösterebilmektedir (Savran ve Demirbaş, 2011; Bayramer, 2015).

Türkiye'de sofralık zeytin ihracatındaki başarısızlığın temel nedenleri arasında sektörün aile işletmeleri yapısında olması, tek düze ve teknolojiden uzak üretim yapılması, pazarlama stratejilerinin yetersiz olması, sofralık zeytin standardının uzun yıllar uygulamada zorunlu olarak yer almaması, uzun sürede işlenmiş zeytin ürünlerinin tuz oranının fazla olmasından ötürü daha çok iç piyasa tüketimine uygun olması, acılık maddesi olan oleuropeinin tam olarak uzaklaştırılamaması, üretim hatalarından kaynaklı salamura yüzeyinde oluşan küf tabakası ve diğer üretici ülkelerin üretimindeki artış ve azalışlar olarak sıralamak mümkündür (Tunalıoğlu, 2003). 
Çizelge 1. Türkiye'de Zeytin ve Zeytinyağı Üretiminin Yıllara Göre Değişimi (Ton) (Anonim, 2019)

\begin{tabular}{|c|c|c|c|c|c|c|}
\hline & 2014 & 2015 & 2016 & 2017 & 2018 & $\begin{array}{c}\text { Değişim } \\
\text { (\%) }\end{array}$ \\
\hline $\begin{array}{c}\text { Toplam zeytinlik } \\
\text { alanı }\end{array}$ & 8.261 & 8.369 & 8.455 & 8.461 & 8.644 & 2.2 \\
\hline $\begin{array}{c}\text { Toplam zeytin } \\
\text { ağacı sayısı (bin } \\
\text { adet) }\end{array}$ & 168.997 & 171.992 & 173.758 & 174.594 & 177.844 & 1.9 \\
\hline $\begin{array}{l}\text { Toplam zeytin } \\
\text { üretimi (bin ton) }\end{array}$ & 1.768 & 1.700 & 1.730 & 2.100 & 1.500 & -28.6 \\
\hline $\begin{array}{l}\text { Sofralık zeytin } \\
\text { üretimi }\end{array}$ & 438.000 & 400.000 & 430.000 & 460.000 & 426.995 & -7.2 \\
\hline $\begin{array}{l}\text { Yağlık zeytin } \\
\text { üretimi }\end{array}$ & 1.330 .000 & 1.300 .000 & 1.300 .000 & 1.640 .000 & 1.073 .472 & -34.5 \\
\hline Zeytinyağı üretimi & 190.000 & 185.000 & 195.000 & 287.041 & 193.613 & -32.5 \\
\hline
\end{tabular}

Tüketici tercihini yaparken güven sağlayan, gereksinimi ve beğeniyi karşılayan, bütçesine uygun ürünü seçmektedir. Üretici ise geleneksel, maliyeti düşük ürün üretmeyi tercih etmektedir. Sofralık zeytin üretimi ve tüketimindeki temel sorunların genel olarak üretici ve tüketicinin bilgi eksikliğinden kaynaklandığı düşünülmektedir. Literatür çalışmaları incelendiğinde tüketicilerin sofralık zeytin tüketim alışkanlıklarına ilişkin sınırlı sayıda kaynak olup zeytinyağı tüketim tercih ve alışkanlıklarının araştırıldığı birçok kaynağa rastlanmıştır (Tsakiridou ve ark., 2006; Matsatsitis ve ark., 2007; Cömert ve ark., 2012; Tunalıŏlu ve ark., 2012; Mtimet ve ark., 2013; Panico ve ark., 2014; Çelik ve ark., 2016).

Bu çalışmanın amacı, Türkiye'de önemli zeytin ve zeytinyağı üretici ve tüketici şehirleri arasında yer alan Manisa ilindeki bireylerin, $5^{\prime} \mathrm{i}$ sosyo-demografik soru olmak üzere 26 seçenekli sorudan oluşan anket ile sofralık zeytin tüketim ve tercihini belirlemektir. Ayrıca sofralık zeytini ne kadar tanıdıkları ve zeytin tüketiminin sağlığa faydalı yönleriyle ilgili ne derecede bilgi sahibi olduklarını araştırmaktır. Böylece elde edilen verilerin hem literatür için kaynak oluşturulabileceği, hem de sofralık zeytin üreticilerine tüketici tercihleri hakkında veri oluşturarak tüketicilerin isteklerini karşılayabilecek üretim yapma imkânı sunulabileceği ön görülmektedir. Ayrıca yapılan anket çalışması ileride yapılabilecek daha geniş kapsamlı anket çalışmaları için de veri tabanı sağlamış olacaktır.

\section{Materyal ve Metot}

Çalışmanın ana materyalini, Manisa il merkezinde tesadüfi olarak seçilen tüketicilere 2017 yılında yapılan anket çalışmasından elde edilen bilgiler oluşturmaktadır. 26 sorudan oluşan anket çalışması 400 tüketiciye yüz yüze görüşme tekniği kullanılarak yapılmıştır. 2017 yılı Türkiye İstatistik Kurumu verilerine göre Manisa ili merkez ilçesi nüfusu 400.686'dır. Bu hedef kitlede $\% 95$ güven aralığında $\alpha=0.05$ için t değeri 1.96'dır. Olayın gerçekleşme olasılığı (p) ve gerçekleşmeme olasılığı (q) eşit ve 0.50 olarak kabul edilmiştir. Araştırmanın örnek hacmi ana kitle oranlarına dayalı kümelendirilmiş tek aşamalı tesadüfi olasılık örnekleme yöntemi kullanılarak aşağıdaki formül ile belirlenmiştir (Meral ve Şahin, 2013).

$\mathrm{n}=\left[\mathrm{t}^{2}(\mathrm{pxq}) / \mathrm{e}^{2}\right.$

$\mathrm{n}=$ Örnekleme alınacak birey sayısı

$\mathrm{t}=$ \%95 önem derecesine karşılık gelen tablo değeri

$p=$ incelenen olayın gerçekleşme olasılığı (\%50) $\mathrm{q}=$ incelenen olayın gerçekleşmeme olasılığı (\%50)

$\mathrm{e}=$ kabul edilen hata payı $( \pm \% 5$ olarak kabul edilmiştir)

$n=(1.96)^{2} \cdot(0.5 \times 0.5) /(0.05)^{2}=384$ 
Elde edilen veriler tanımlayıcı istatistikler ile değerlendirilmiştir. Bunun için PASW Statistics Ver.18 paket programı kullanılarak analiz edilmiştir (PASW, 2009). Araştırma verileri değerlendirilirken değişken olarak cinsiyet, yaş, eğitim seviyesi, gelir düzeyi alınmış; istatistik analiz olarak $X^{2}$ testi kullanılmıştır.

\section{Bulgular ve Tartışma}

\section{Demografik Özellikler}

Diğer tüm gıda ürünlerinde olduğu gibi sofralık zeytinde de tüketim alışkanlıkları ürünlerin kalite, fiyat ve hijyen özelliklerine, tüketicilerin zevk ve tercihlerine bağlı olarak değişkenlik gösterebilmektedir. Üretici firmalar pazarda ürünün konumunu belirlerken demografik ve sosyo-ekonomik özellikleri önemli bir sınıflandırma ölçütü olarak kullanmaktadırlar (Ağır ve ark., 2018). Tüketicilerin satın alma davranışlarını, ürünün özelliklerinin yanı sıra pazarda yer alan hedef kitlenin demografik, psikolojik, sosyolojik ve kültürel özelliklerin de etkilediği bildirilmiştir. Tüketicilerin yaşı, mesleği, ekonomik gücü, yaşam standardı, kişiliği gibi faktörler ve beraberinde ürünün fiyatı, markası, toplumsal yönelme satın almayı etkileyen temel faktörlerdir (Özdemir ve ark., 2017). Bu çalışmadan elde edilen verilere göre tüketicilerin demografik ve sosyo-ekonomik özellikleri Çizelge 2'de verilmiştir. Tüketici davranışını etkileyen önemli değişkenlerden birisi tüketicinin cinsiyetidir. Ankete katılan tüketicilerin \%54'ünü kadınlar, \%46'sını erkekler oluşturmaktadır. Tüketicilerin yaş ortalaması incelendiğinde $\% 28.46$ 'sının 46 yaş üstü, $\quad \% 26.15$ 'nin $31-45$ yaş aralığında, \%45.38'nin 18-30 yaş aralığında olduğu gözlemlenmiştir. Tüketicilerin eğitim durumları incelendiğinde $\% 43,75$ ile büyük bir kısmı lise mezunları, \%31.50'lik kısmı üniversite mezunları, \%19.50'lik kısmı ilköğretim mezunları, \%3.75'ini yüksek lisans ve doktora mezunları, kalan kısmı ise okuryazar olmayan kitle oluşturmaktadır. Tüketiciler mesleklerine göre değerlendirildiğinde yarısına yakın kısmını \%44.75 payla çalışan kesim oluştururken, kalan kısmı \%32.25 ile öğrenciler, \%7.75 ile emekliler oluşturmaktadır. Araştırmaya katılanların çoğunluğu (\%40.75) 1501-3000 TL gelir grubunda yer almaktadır.

\section{Tüketicilerin Zeytin Tüketim Alışkanlıkları}

Anket uygulanan kişilerin zeytin tüketimlerine ilişkin bulgular Çizelge 3'de verilmiştir. Araştırmaya katılan bireylerin günlük olarak, \%6'sı hiç zeytin tüketmezken, \%22.75'i 0-5 adet zeytin, \%35'i 5-10 adet zeytin, \%19.75'i $10-15$ adet zeytin, \%12'si ise 15 adetten fazla zeytin tükettiğini bildirmiştir. Söz konusu anket bulguları istatistiksel olarak irdelendiğinde, cinsiyet, yaş ve gelir durumunun günlük zeytin tüketim niceliği üzerine istatistiksel olarak önemli bir etkisinin olmadığı belirlenmiştir $(P>0,05)$ (Çizelge 4). Hane halkının aylık zeytin tüketimleri incelendiğinde \%38.50'sinin 1 kg'dan az, \%34.25'inin 1-2 kg arası, \%20.75'inin 2-3 kg arası, \%6.50'sinin ise $3 \mathrm{~kg}$ 'dan fazla zeytin tükettiği tespit edilmiştir. Yapılan istatistiksel analize göre, cinsiyet, yaş ve gelir seviyesi ile aylık zeytin tüketimi arasındaki ilişkinin önemli olduğu belirlenmiştir $(P<0.05) \quad$ (Çizelge 4). Tüketicilerin büyük çoğunluğu (\%75.75) genelde zeytini kahvaltıda tüketmeyi tercih ettiğini belirtmiştir. Diğer tercihini seçen \%19.50'lik kısmın ise atıştırmalık olarak günün herhangi bir saatinde zeytin tükettiği düşünülmektedir. Meral ve Şahin (2013), Kahramanmaraş ilinde yaptıkları anket çalışmasında tüketicilerin \%55.99'unun aylık 0.6-1.5 kg arasında zeytin tükettiğini, aylık ortalama hane halkı zeytin tüketiminin $1.20 \mathrm{~kg}$ ve aylık kişi başına düşen zeytin tüketim miktarının ise 0.31 kg olduğunu belirlemişlerdir. Benzer şekilde Cankurt ve ark. (2011), Aydın ilinde yaptıkları anket çalışmasında yıllık ortalama zeytin tüketimini $30.1 \mathrm{~kg}$, kişi başına düşen zeytin tüketim miktarını ise $9.4 \mathrm{~kg}$ olarak bildirmişlerdir.

Bölgedeki zeytin temini kolaylığından ve yine bölgede üretimin fazla olmasından dolayı tüketicilerin büyük bir kısmı (\%30.71) hazır market ürünlerini kullanmak yerine direkt üreticinden almayı tercih etmektedir (Çizelge 3). Katılımcıların \%17.01'i zeytini marketten temin ederken \%14.21'i şarküteriden, \%9.9'u pazardan, \%9.64'ü de AVM'den satın aldıklarını belirtmişlerdir. Demografik değişkenlere bağlı olarak değerlendirildiğinde cinsiyet farkı gözetmeksizin yaş ve satın alınan yer tercihi arasında anlamlı bir ilişkinin olduğu tespit edilmiştir $(P<0.001)$ (Çizelge 4). 
Çizelge 2. Tüketicilere ait demografik ve sosyo-ekonomik bulgular

\begin{tabular}{|c|c|c|}
\hline Parametre & Kategori & Oran (\%) \\
\hline \multirow{3}{*}{ Cinsiyet } & Erkek & 46 \\
\hline & Kadın & 54 \\
\hline & $18-30$ Yaş & 45.38 \\
\hline \multirow[t]{4}{*}{ Yaş } & $31-45$ yaş & 26.15 \\
\hline & 46 üstü & 28.46 \\
\hline & Okur-yazar değil & 1.5 \\
\hline & İlköğretim & 19.5 \\
\hline \multirow[t]{6}{*}{ Eğitim Durumu } & Lise & 43.75 \\
\hline & Üniversite & 31.5 \\
\hline & Yüksek L. /Doktora & 3.75 \\
\hline & İşsiz & 15.25 \\
\hline & Öğrenci & 32.25 \\
\hline & Serbest Meslek & 14.75 \\
\hline \multirow{5}{*}{ Meslek } & Memur & 15.75 \\
\hline & Özel Sektör & 14.25 \\
\hline & Emekli & 7.75 \\
\hline & 750'den az & 2.25 \\
\hline & $750-1500 \mathrm{TL}$ & 13.75 \\
\hline \multirow[t]{3}{*}{ Hane Gelir Düzeyi } & $1501-3000 \mathrm{TL}$ & 40.75 \\
\hline & $3001-5000 \mathrm{TL}$ & 33 \\
\hline & 5000 TL Üzeri & 10.25 \\
\hline
\end{tabular}

Zeytin satın alınan yer tercihine ilişkin ulaştığımız bulgular, Meral ve Şahin (2013)'in çalışmalarında elde ettikleri bulgularla uyumludur. Araştırıcılar, Kahramanmaraş ilinde yaptıkları anket çalışmasında tüketicilerin çoğunluğunun (\%35.6) direkt üreticiden, çok az bir kısmının ise pazar ya da marketten hazır zeytin almayı tercih ettiği sonucuna varmışlardır (Meral ve Şahin, 2013). Aydın ilinde ise tüketicilerin \%47.6'sı zeytini kendi üretirken, \%17.1'i tanıdıklarından aldığını, \% 15.9'nu da süper marketlerden satın aldığını bildirmiştir (Cankurt ve ark., 2011). Özdemir ve ark., (2017) çalışmalarında tüketicilerin çoğunluğunun (\%61) açık zeytinleri tadarak marketten satın aldıklarını, kalan kısmın ise (\%39) ambalajlı zeytin tercih ettiklerini tespit etmişlerdir. Yine çalışma sonuçlarına göre tüketiciler market reyonlarında satılan açık zeytinleri, pazarda satılan zeytinlere göre daha güvenilir bulmaktadır. Bu durumun market reyonunda satılan zeytinlerin gerekli belge ve kayıtlarından dolayı olabileceği bildirilmiştir (Özdemir ve ark., 2017). Çizelge 4'de de görüldüğü üzere temin edilen yerin hane gelirinden önemli ölçüde etkilendiği, hane geliri arttıkça marketten temin etme eğiliminin de arttığı belirlenmiştir $(P<0.05)$. 
Çizelge 3. Tüketicilerin zeytin tüketim alışkanlıklarına ilişkin bulgular

\begin{tabular}{|c|c|c|}
\hline Parametre & Kategori & Oran (\%) \\
\hline & Hiç & 6 \\
\hline & $0-5$ arası & 27.25 \\
\hline \multirow[t]{5}{*}{ Günlük Zeytin Tüketimi (Bireysel, Adet) } & 5-10 arası & 35 \\
\hline & $10-15$ arası & 19.75 \\
\hline & 15 üstü & 12 \\
\hline & $1 \mathrm{~kg}$ altı & 38.5 \\
\hline & $1-2 \mathrm{~kg}$ & 34.25 \\
\hline \multirow[t]{4}{*}{ Aylık Zeytin Tüketimi (Hane halkı olarak, Kg) } & $2-3 \mathrm{~kg}$ & 20.75 \\
\hline & 3kg üstü & 6.5 \\
\hline & Kahvaltı & 75.75 \\
\hline & Öğle Yemeği & 3 \\
\hline \multirow{6}{*}{ Zeytin Tüketimi Tercih Edilen Öğünler } & Akşam & 1 \\
\hline & Öğleden sonra & 0.75 \\
\hline & $\begin{array}{l}\text { Diğer (atıştırmalık olarak günü herhangi } \\
\text { bir saatinde) }\end{array}$ & 19.5 \\
\hline & Pazar & 9.9 \\
\hline & Şarküteri & 14.21 \\
\hline & Bakkal & 4.06 \\
\hline \multirow[t]{6}{*}{ Zeytin Alınan Yerler } & Market & 17.01 \\
\hline & AVM & 9.64 \\
\hline & Kendimiz üretiyoruz & 14.47 \\
\hline & Diğer (direkt üretici) & 30.71 \\
\hline & Kaliteli ve temiz & 49.47 \\
\hline & Ucuz & 5 \\
\hline \multirow[t]{5}{*}{ Satın Aldığınız Yeri Tercih Etme Sebepleri } & Yakın & 10.79 \\
\hline & Veresiye & 2.37 \\
\hline & Diğer (bilindik ve güvenilir olması) & 32.37 \\
\hline & Temiz & 28.62 \\
\hline & Ekonomik & 13.41 \\
\hline \multirow[t]{5}{*}{ Kendi Üretme Sebepleri } & İçeriği bilindik & 19.2 \\
\hline & Katkısız & 17.03 \\
\hline & $\begin{array}{l}\text { Diğer (kendi zeytin bahçesi olanlar, } \\
\text { zeytin yetiştiriciliği yapanlar }\end{array}$ & 21.74 \\
\hline & 0-10 TL & 21.77 \\
\hline & $10-15 \mathrm{TL}$ & 31.39 \\
\hline \multirow[t]{3}{*}{ Aylık Zeytin Harcaması (TL) } & $15-20 \mathrm{TL}$ & 26.33 \\
\hline & $20-25 \mathrm{TL}$ & 11.65 \\
\hline & 25 TL üstü & 8.86 \\
\hline
\end{tabular}


Çizelge 4. Ankete Katılan Bireylerin Demografik Özellikleri ile Anket Soruları Arasındaki ilişkilerin $\mathrm{X}^{2}$ ve $\mathrm{P}$ değerleri

\begin{tabular}{|c|c|c|c|c|c|c|c|c|}
\hline & \multicolumn{2}{|c|}{ Cinsiyet } & \multicolumn{2}{|c|}{ Yaş } & \multicolumn{2}{|c|}{ Gelir seviyesi } & \multicolumn{2}{|c|}{ Eğitim seviyesi } \\
\hline & $x^{2}$ & $\mathbf{P}$ & $x^{2}$ & $\mathbf{P}$ & $\mathrm{X}^{2}$ & $\mathbf{P}$ & $x^{2}$ & $\mathbf{P}$ \\
\hline $\begin{array}{l}\text { Satın alınan } \\
\text { yer }\end{array}$ & 10.148 & 0.119 & 75.338 & $0.000 *$ & 29.088 & 0.217 & 36.159 & 0.053 \\
\hline $\begin{array}{l}\text { Aylık tüketim } \\
\text { miktarı }\end{array}$ & 13.183 & $0.004^{*}$ & 59.339 & $0.000 *$ & 26.244 & $0.010 *$ & 13.928 & 0.305 \\
\hline $\begin{array}{l}\text { Kalp damar } \\
\text { sağlığı }\end{array}$ & 0.732 & 0.392 & 19.185 & $0.004 *$ & 3.156 & 0.532 & 4.346 & 0.361 \\
\hline Kolesterol & 0.402 & 0.526 & 20.474 & $0.002 *$ & 5.772 & 0.217 & 14.820 & $0.005^{*}$ \\
\hline E vitamini & 15.150 & $0.000^{*}$ & 8.089 & 0.232 & 8.377 & 0.079 & 0.339 & 0.987 \\
\hline Kanser & 9.268 & $0.010^{*}$ & 15.007 & 0.241 & 3.827 & 0.872 & 7.582 & 0.475 \\
\hline Sağlıklı mı? & 0.890 & 0.346 & 6.337 & 0.387 & 13.267 & $0.010 *$ & 7.726 & 0.102 \\
\hline Alerji & 0.121 & 0.728 & 2.608 & 0.856 & 6.579 & 0.160 & 1.750 & 0.782 \\
\hline Zeytin nedir? & 8.305 & $0.040 *$ & 23.192 & 0.183 & 15.125 & 0.235 & 23.056 & $0.027^{*}$ \\
\hline
\end{tabular}

${ }^{*} \alpha=0.05$ seviyesinde istatistiksel olarak farklılık anlamlıdır.

Tüketicilerin büyük çoğunluğu (\%49.47) satın aldığı yeri tercih etme sebebinin kaliteli ve temiz olmasından dolayı olduğunu bildirmiştir. Zeytinyağı pazarında tüketici davranışlarının incelendiği bir çalışmada, anket yapılan bireylerin $\% 61$ 'i kooperatif üretici markaları tercih ederken yalnızca \%11'i lider markaları tercih etmiştir (Salazar-Ordonez ve ark., 2018).

Bireylere eğer zeytini kendileri üretiyorsa bunun sebebinin ne olduğu sorulmuştur. Buna göre \%28.62'si temiz olması, \%19.20'si içeriğinin biliniyor olması, \%17.03'ü katkısız olması, \%13.41'i ekonomik olması, \%21.74'ü ise zeytin ağaçları olması sebebiyle zeytini kendilerinin ürettiklerini belirtmişlerdir. Tüketicilerin \%21.77'si zeytine ayda 1-10 TL arası, \%31.39'u 10-15 TL, \%26.33'ü 15-20 TL, \%11.65'i 20-25 TL arası, \%8.86'sı 25 TL den fazla harcama yapmaktadır. Hane geliri ile aylık zeytin harcaması arasında anlamlı bir ilişki bulunmuştur $(P<0.05)$. Meral ve Şahin (2013) ise Kahramanmaraş'ta yaptıkları anket çalışmasında tüketicilerin \%42.7'sinin sofralık zeytine ayda 9-11 TL aralığında bir harcama yaptığını bildirmişlerdir. 2013 yılına göre zeytine harcanan fiyatın yüksek çıkmasının anket çalışmasının yaz ayında yapılmasından kaynaklandığı, çünkü bölgede çok tüketilen ve fiyatı siyah zeytine göre daha uygun olan yeşil zeytinin kış aylarında üretildiği belirtilmiştir.

Anket uygulanan kişilerin zeytin tercihlerine ilişkin bulgular Çizelge 5'de verilmiştir. Zeytinde renk tercihinde yeşil zeytin ilk sırayı alırken (\%33.5), aroma tercihinde ankete katılanların çoğunluğu (\%31.75) ekşimsi seçeneğini tercih etmiştir. Çoğunlukla ekşimsi aromaya sahip yeşil zeytin tercihi, renk ve aromaya ilişkin tüketici yanıtlarının tutarlı olduğunu göstermektedir. Kahramanmaraş ilinde yapılan anket çalışmasında tüketicilerin \%82.6'sı siyah, \%79.2'si ise yeşil zeytin tükettiğini bildirmiştir.

Gelir grupları ile siyah ve yeşil zeytin tüketimi ilişkisi incelendiğinde, gelir arttıkça siyah zeytin tüketiminin de arttığı sonucuna varılmıştır (Meral ve Şahin, 2013). Özdemir ve ark. (2016) ise Türkiye genelinde yaptıkları anket çalışmasında tüketicilerin \%73'ünün siyah, \%26'sının yeşil, \%1'nin ise rengi dönük zeytin tercih ettiklerini belirlemiş̧lerdir. Tüketicilerin yeşil zeytini ekşi ve tuzlu olduğundan dolayı daha az tercih ettiklerini bildirmişlerdir. 
Çizelge 5. Anket uygulanan kişilerin zeytin tercihlerine ilişkin bulgular

\begin{tabular}{|c|c|c|}
\hline \multirow[t]{2}{*}{ Parametre } & Kategori & Oran (\%) \\
\hline & Yeşil & 33.5 \\
\hline \multirow[t]{4}{*}{ Tercih Edilen Zeytin Rengi } & Siyah & 21.25 \\
\hline & Fark etmez & 45.25 \\
\hline & $\mathrm{Acl}$ & 11.5 \\
\hline & Ekşimsi & 31.75 \\
\hline \multirow[t]{5}{*}{ Tercih Edilen Zeytin Aroması } & Buruk & 22.75 \\
\hline & Hafif tatlımsı & 24.25 \\
\hline & Diğer & 9.75 \\
\hline & Cam kavanoz & 32.83 \\
\hline & Teneke & 6.27 \\
\hline \multirow[t]{6}{*}{ Tercih Edilen Zeytin Ambalaj Türü } & Plastik & 1.75 \\
\hline & Poşet & 19.55 \\
\hline & $\begin{array}{l}\text { Fark etmez (ambalajlı veya } \\
\text { ambalajsız) }\end{array}$ & 39.6 \\
\hline & Edremit & 7.75 \\
\hline & Gemlik & 16.75 \\
\hline & Tuzsuz sele & 7.25 \\
\hline \multirow[t]{5}{*}{ Tercih Edilen Sofralık Zeytin Türleri } & Çizik yeşil & 19.25 \\
\hline & $\begin{array}{l}\text { Diğer (iri, küçük, dolgulu, } \\
\text { çeşnili, Akhisar Uslu, Memecik } \\
\text { ve/veya Domat gibi diğer } \\
\text { çeşitler) }\end{array}$ & 48.75 \\
\hline & Lezzet & 24.49 \\
\hline & Renk & 4.04 \\
\hline & İrilik & 3.79 \\
\hline \multirow[t]{3}{*}{ Zeytin Alımında Dikkat Edilen Noktalar } & Marka & 5.56 \\
\hline & Fiyat & 1.52 \\
\hline & $\begin{array}{c}\text { Diğer (tuzlu, ekşi, acımsı, } \\
\text { baharat aromalı) }\end{array}$ & 60.67 \\
\hline
\end{tabular}

Ambalaj seçiminde tüketicilerin \%32.83'lük kısmı sağıklı olması ve görünümün daha net olması açısından cam kavanozu tercih ederken, \%39.60 gibi büyük bir kısmı fark etmez yanıtını vermiştir (Çizelge 5). Fark etmez yanıtı bireylerin zeytini ambalajlı ya da ambalajsız olarak satın aldıklarını göstermektedir. Gıdalarda renk ve parlaklık tüketici tarafından ilk algılanan özelliklerdir. Bu nedenle satın almada önemli rol oynamaktadır.

Paket içerisinde satılan zeytinlerin lezzetine bakmak da mümkün olmadığından görünüş özelliği ön plana çıkmaktadır (Özdemir ve ark., 2016). Meral ve Şahin (2013), çalışmalarında tüketicilerin \%78.9' unun ambalajsız, \%51'nin ambalajlı ve markalı, \%4.4'ünün ise ambalajı fakat markasız zeytin satın aldığını belirtmişlerdir. Özdemir ve ark., (2017), Türkiye genelinde tüketicinin ambalajlı ve ambalajsız sofralık zeytin satın alma tercihleri üzerine yaptıkları anket çalışmasında, çoğunluğun (\%61) açık zeytin satan yerlerden tadına bakarak satın almayı tercih ederken, \%39'unun ambalajlı zeytin satın almayı tercih ettiği sonucuna varmışlardır. Yine aynı çalışmada neden ambalajlı zeytin almayı tercih etmiyorsunuz sorusuna ise tüketiciler zeytinin tadına bakamaması, fiyatının daha 
yüksek olması, ambalajdan zeytinin görünmemesi ve ambalajda yeterli bilginin verilmemesinden kaynaklı güvenilir olmadığını düşündükleri yanıtını vermişlerdir. Ankete katılan tüketicilerin zeytin seçimi incelendiğinde, \%19.25'inin çizik yeşil zeytin, \%16.25'inin Gemlik kıvırcık siyah zeytin, \%7.75'inin Edremit tipi zeytin, \%7.25'inin tuzsuz siyah sele zeytin, \%48.75'inin de diğer seçeneğini tercih ettiği belirlenmiştir. Diğer seçeneği iri, küçük, dolgulu ve çeşnili zeytin çeşitleri ile Akhisar Uslu, Memecik ve/veya Domat gibi diğer çeşitleri kapsayabilmektedir. Panico ve ark (2014)'nin italyan ekstra naturel sızma zeytinyağı tercihleri üzerine yaptıkları anket çalışmasında, sonuçlarımıza benzer olarak zeytin çeşidi tercihinde olduğu gibi tüketicilerin zeytinyağı çeşidi tercihinde de hassas oldukları sonucuna varılmıştır. Meral ve Şahin (2013), anket çalışmalarında tüketicilerin \%86.2'sinin Gemlik tip zeytini, \%79.69'unun ise Nizip/Kilis yağlık zeytini tercih ettikleri sonucuna varmışlardır. Elde ettiğimiz sonuçlar Meral ve Şahin (2013)'in sonuçlarıyla karşılaştırıldığında, zeytin tercihinde damak zevkine bağlı olarak bölgesel farklılıkların önemli olduğu görülmektedir.

Gıdalarda yapılan duyusal analizler gıdaların birçok özelliğinin değerlendirilmesinde rol almasına rağmen, lezzet bu özelliklerin en başında gelmektedir. Türkiye'de satılan zeytinlerin \%80 gibi büyük bir kısmının açıkta yani ambalajsız olarak satıldığı bildirilmiştir. Tüketiciler açıkta satılan zeytinlerin önce tatlarına bakmakta daha sonra satın almaya karar vermektedir. Bu nedenle de lezzet ve görünüm tüketici tercihini oldukça etkilemektedir (Özdemir ve ark., 2016). Anket sonuçlarına göre de tüketicilerin zeytin tercihlerinde ilk sırayı lezzet almaktadır (\%24.49). Bunun dışında renk, irilik, fiyat, marka gibi birçok faktörün de etkili olduğu görülmektedir. Diğer seçeneğini tercih eden \%60.67'lik kısmın da zeytini tuzlu, ekşi, acımsı, baharatlı oluşuna göre tercih ettikleri akla gelmektedir. Meral ve Şahin (2013)'e göre ise genel olarak tüketiciler en çok lezzete, en az çekirdek rengine dikkat etmektedir.

Sofralık zeytin tercihi üzerine yapılan başka bir anket çalışması sonuçlarına göre tüketicilerin \%52'sinin zeytinlerin çekirdek rengine dikkat ettiği, \%73'ünün orta derece buruşuk siyah zeytin tercih ettiği ve genel olarak siyah zeytin tercih edilmemesinin sebebinin çok tuzlu olmasından dolayı (\%63) olduğu bildirilmiştir (Özdemir ve ark., 2016). Bizim bulgularımıza benzer olarak, Özdemir ve ark., (2017) da başka bir çalışmalarında tüketicilerin çoğunluğunun zeytin alırken lezzetine ve fiyatına bakarken, çok az bir kısmının çekirdek rengine dikkat ettiğini bildirmişlerdir.

\section{Tüketicilerin Zeytinin Sağlığa Yararları Hakkındaki Bilgi Düzeyleri}

Anket uygulanan kişilerin zeytin hakkındaki bilgilerine ilişkin bulgular Çizelge $6^{\prime}$ da verilmiştir. Elde edilen verilere göre tüketicilerin \%44.50'si zeytini meyve, \%17.25'i sebze, \%37.25'i ise yağlı tohum olarak bilmektedir. Ankete katılan bireylerin cinsiyet ve eğitim seviyeleri ile zeytinin ne olduğuyla ilgili bilgileri arasında anlamlı bir ilişki tespit edilmiştir $\quad(P<0.05)$. Tüketicilerin \%65.52'si zeytinin kalp damar sağlığını koruduğunu bildiğini, kalan kısım ise bunu bilmediğini belirtmiştir. Ankete katılan bireylerin yaşının zeytinin kalp damar sağlığını koruduğuyla ilgili bilgi düzeyi arasında anlamlı bir ilişki bulunmuştur $(P<0.001)$. Tüketicilerin yarısının (\%51) zeytin tüketimiyle kolesterolünü dengede tutabileceğini bildiği görülmektedir, ancak diğer yarısı aksini bildirmiştir. İstatistiksel analiz sonuçlarına göre bireylerin yaş ve eğitim seviyeleri ile zeytinin kolesterolü dengede tuttuğuyla ilgili bilgi düzeyleri arasında anlamlı bir ilişki tespit edilmiştir $(P<0.001)$. Tüketicilerin yarıdan fazlası (\%68.50) zeytin tüketimi sayesinde katarakt riskinden korunabileceğini bilmemektedir.

Yine \%58.75 oranında bir çoğunluk zeytinin E vitaminince zengin olduğunu ve buna bağlı olarak da yaşlanmayı geciktirici etkisi olduğunu bilmemektedir. Ancak \%52.38'i zeytin tüketimiyle kanser riskinin azaldığını bilmektedir. Demografik özellikler arasında yalnızca cinsiyet ile tüketicinin zeytinin $E$ vitamini içeriği ve kanserden korunmada etkili olduğu hakkındaki görüşleri arasında önemli bir ilişki bulunmuştur $(P<0.001)$. Sonuçlar değerlendirildiğinde tüketicilerin bir kısmının zeytinin sağlık açısından yararlarını bilmesine rağmen, azımsanamayacak kadar yüksek bir kısmın da zeytinin sağlık üzerine faydaları ile ilgili yetersiz bilgi sahibi oldukları sonucuna varılmıştır. 
Çizelge 6. Anket uygulanan kişilerin zeytin hakkındaki bilgilerine ilişkin bulgular

\begin{tabular}{lcc}
\multicolumn{1}{c}{ Parametre } & Kategori & Oran (\%) \\
& & 37.25 \\
Zeytinin Ne Olduğı & Yağlı Tohum & 17.25 \\
& Sebze & 44.5 \\
Zeytin tüketiminin kalp damar sağlığını koruyup korumadığı & Meyve & 1 \\
& Diğer & 65.52 \\
Zeytin tüketiminin kolesterolü dengede tutup tutamayacağı & Hayır & 34.75 \\
& Evet & 51 \\
Zeytinin ilerleyen yaşlarda katarak riskini azaltıp azaltmadığı & Hayır & 49 \\
& Evet & 31.5 \\
Zeytinin E vitamini açısından zengin olup olmadığı & Hayır & 68.5 \\
& Evet & 41.25 \\
Zeytinin kanserden korunmada etkili olup olmadığı & Hayır & 58.75 \\
& Evet & 52.38 \\
Sofralık zeytin üretiminde boya kullanılıp kullanılmadı̆̆ı & Hayır & 47.62 \\
& Evet & 30 \\
Piyasadan satın alınan zeytinlerin sağlıklı olup olmadığı & Hayır & 70 \\
Tüketicilerde zeytin alerjisi olup olmadığı & Evet & 48.75 \\
\hline
\end{tabular}

Zeytin üretimini insanların biraz daha güvenilir bulmasını 'zeytinde boya olduğunu düşünüyor musunuz?' sorusuna çoğunluğun (\%70) hayır cevabını vermesi doğrulamaktadır. Zeytin üreticilerinin hijyene gereken önemi vermediği, gıdaların uzun süre dayanması için kullanılan katkı maddeleri gibi etkenler göz önünde bulundurulduğunda, ankete katılan bireylerin çoğunluğunun (\%51.25) piyasadan aldığı ürünleri sağlıksız bulduğu cevabını destekler niteliktedir. Katılımcıların \%95.50'lik kısmı ise zeytine alerjisi olmadığını bildirmiştir. Ankete katılan bireylerin Demografik özellikleri ve zeytin alerjisi arasındaki ilişki önemsiz bulunmuştur $(P>0.05)$.

\section{Sonuç}

Manisa il merkezinde bireylerin zeytin tüketim bilgi, tutum ve alışkanlıklarının belirlenmesine yönelik yapılan anket çalışmasında cinsiyet, yaş, gelir düzeyi gibi demografik özelliklere göre tüketilen sofralık zeytin çeşit ve miktarının farklı olduğu saptanmıştır. Tüketicilerin çoğu (\%75.75) zeytini kahvaltıda tüketmektedir. Zeytin satın alınan yer tercihinde kaliteli ve temiz olduğundan güvendikleri tanıdık kişiler ilk sırayı almaktadır. Fiyat \%5'lik oranla son sırada yer almıştır.
Tüketicilerin çoğu $(\% 31,75)$ zeytinde ekşimsi aromayı ve yeşil rengi $(\% 33,5)$ tercih etmiştir. Ambalajlı gıda tüketme görüşünün aksine, sofralık zeytinin ambalajlı olmasına ve markasına önem verilmediği tespit edilmiştir. Genel olarak bakıldığında tüketicilerin sağlık risklerine karşı hassas oldukları ve kendilerini bu tehlikelere karşı korumaya çalıştıkları saptanmıştır. Ancak sonuçlara göre tüketicilerin büyük bir kısmının zeytinin sağlığa yararı hakkındaki bilgisi orta ve düşük seviyelerdedir. Literatürde tüketicinin, zeytinin sağlığa faydaları hakkında bilgi düzeylerine ilişkin çalışmaya rastlanmamıştır. Bu yüzden zeytinin alışılmış tüketiminden ziyade sağıı açısından yararlarının tüketicilere bilimsel verilerle aktarılması gerekmektedir. $\mathrm{Bu}$ kapsamda sofralık zeytin üretim yöntemleri, kalitesi üzerine çalışmaların arttırılması önem taşımaktadır. Manisa gibi zeytin yetiştiriciliğinin yüksek olduğu bir bölgede halkın sofralık zeytin konusundaki bilgilerinin orta düzeyde olması, zeytin tüketim alışkanlıklarının çok fazla olmadığını göstermektedir. Sofralık zeytin işletmeleri genellikle küçük aile tipi işletmelerden oluşmaktadır. Bu işletmelerde hijyenik ve teknik alt yapı yetersizlikleri ile birlikte, büyük bir çoğunluğu işletme ile ilgili 
gerekli yasal zorunlulukları yerine getirememekte ve üretimlerini kayıt dışı sürdürmektedirler. İşletmelerin hijyen koşullarının iyileştirilmesi ve alt yapı eksikliklerinin giderilmesi amacıyla kontrol ve denetimlerin yetkili kuruluşlarca etkin bir şekilde yapılması öngörülmektedir. Ülkemiz ekonomisinde önemli bir yere sahip olan sofralık zeytin üretiminin tüketici isteklerine uygun şekilde gerçekleştirilmesinin tüketici memnuniyetini arttıracağı, bu durumun tüketim tercih ve miktarlarına artış olarak yansıyacağı ve bu sayede üreticiyi daha kârlı konuma getireceği düşünülmektedir.

\section{Kaynaklar}

Ağır, M., Boran, C., Özden, F., Artukoğlu, M. M. 2018. Zeytinyağında Tüketici Tercihleri Üzerine Bir Araştırma: İzmir ilii Dikili İlçesi Örneği. Ege Üniversitesi Ziraat Fakültesi Dergisi, 55(4): 441-451.

Anonim 2018. T.C. Gümrük ve Ticaret Bakanlığı Kooperatifçilik Genel Müdürlüğü 2017 Yılı Zeytin ve Zeytinyağı Raporu.

Anonim 2019. Tarımsal Ekonomi ve Politika Geliştirme Enstitüsü, Tarım Ürünleri Piyasaları: Zeytinyağı.

Baş, T. 2013. Anket Nasıl Hazırlanır? Nasıl Uygulanır? Nasıl Değerlendirilir? Seçkin Yayıncılık,Ankara, Türkiye, $263 \mathrm{~s}$.

Bayramer, G. 2015. Türkiye'nin sofralık zeytin ve zeytinyağı ihracatındaki sorunların değerlendirilmesi. Adanan Menderes Üniversitesi Fen Bilimleri Enstitüsü Tarım Ekonomisi Anabilim Dalı Yüksek Lisans Tezi, Aydın, 160s.

Cömert, M., Adıyaman, S., Özkaya, D.F. 2012. Yerel halkın zeytinyağı ile ilgili bilgi düzeyinin belirlenmesi : Gölbaşı, Ankara örneği. Zeytin Bilimi, 3(1): 1-9.

Çam, E. 2018. Zeytin ve Zeytinyağı Sektörü Raporu. AR\&GE Bülten, 7-11.

Çelik, M., Aksoy, M., Özkaya, D.F. 2016. Üniversite öğrencilerinin zeytinyağı bilgi düzeylerini belirlemeye yönelik bir araştırma. Zeytin Bilimi, 6(2): 69-75.

Çetin, B., Tipi, T. 2000. Türkiye'de sofralık zeytin üretimi ve pazarlaması. Türkiye 1 . Zeytincilik Sempozyumu, 6-9 Haziran 2000, Bursa, 34-40s.

Matsatsinis, N.F., Grigoroudis, E., Samaras, A.P. 2007. Comparing distributors' judgements to buyers'preferences. A consumer value analysis in the Greek olive oil market. International Journal of Retail \& Distribution Management, 35(5): 342-362.

Meral, Y., Şahin, A. 2013. Tüketicilerin Coğrafi Işaretli Ürün Algısı: Gemlik Zeytini Örneği. Kahramanmaraş Sütçü Imam Üniversitesi Doğa Bilimleri Dergisi, 16(4): 16-24.

Mtimet, N., Zaibet, L., Zairi, C., Hzami, H. 2013. Marketing Olive Oil Products in the Tunisian Local Market: The Importance of Quality Attributes and Consumers' Behavior. Journal of International Food \& Agribusiness Marketing, 25: 134145.

Özdemir, Y., Kayahan, S., Keskinel, Ö. 2016. Tüketicinin sofralık zeytin tercihlerinin belirlenmesi. Bahçe, 45(1): 11-19.

Özdemir, Y., Kayahan, S., Keskinel, Ö. 2017. Tüketicinin ambalajlı ve ambalajsız sofralık zeytin satın alma tercihleri ve buna etki eden bazı faktörler. Gıda ve Yem Bilimi-Teknolojisi Dergisi, 17: 4150.

Özinanç, G. 2018. Türkiye'nin farklı coğrafi bölgelerine ait natürel sızma zeytinyağı örneklerinin yağ asidi ve sterol bileşenleri ile yakın kızılötesi spektrumları arasındaki ilişkiler. Yıldız Teknik Üniversitesi Fen Bilimleri Enstitüsü Kimya Anabilim Dalı Yüksek Lisans Tezi, İstanbul, 135s.

Panico, T., Del Giudice, T., Caracciol, F. 2014. Quality dimensions and consumer preferences: A choice experiment in the Italian extra-virgin olive oil market. Agricultural Economics Reviews, 15(2): 100-112.

PASW Statistics 18. 2009. SPSS Inc, Chicago, USA.

Sakar, E., Ünver, H. 2011. Türkiye'de zeytin yetiştiriciliğinin durumu ve Ülkemizde yapılan bazı seleksiyon ve adaptasyon çalışmaları. Harran Tarım ve Gıda Bilimleri Dergisi, 15(2): 19-25.

Salazar-Ordóñez, M., Entrena, M.R., Cabrera, E.R., Henseler, J. 2018. Survey data on consumer behaviour in olive oil markets: The role of product knowledge and brand credence. Data in Brief, 18: 1750-1757.

Savran, M.K., Demirbaş, N. 2011. Türkiye'de sofralık zeytinde kalite sorunu ve öneriler. Uludağ Üniversitesi Ziraat Fakültesi Dergisi, 25(2): 89-99. 
Tiryakioğlu, M. 2011. Sofralık zeytin üretimi ve dış satım olanakları üzerine bir araştırma: Akhisar ilçesi örneği. Ege Üniversitesi Fen Bilimleri Enstitüsü Tarım Ekonomisi Anabilim Dalı Yüksek Lisans Tezi, İzmir, 77s.

Tsakiridou, E., Mattas, K., Kalogianni, I.T. 2006. The Influence of Consumer Characteristics and Attitudes on the Demand for Organic Olive Oil. Journal of International Food \& Agribusiness Marketing, 18(3/4): 23-31.

Tunalıoğlu, R. 2003. Sofralık zeytin. Tarımsal Ekonomi Araştırma Enstitüsü Bakış, 4(5): 1-4.

Tunalıoğlu, R., Çobanoğlu, F., Cankurt, M., Armağan, G. 2012. Zeytinyağı tüketici davranışları. 10. Ulusal Tarım Ekonomisi Kongresi, 5-7 Eylül 2012, Konya, 853-862s. 